\title{
Some physicochemical, textural properties and acrylamide contents of chips produced from the teleme of white cheese
}

\section{Beyaz peynir telemesinden üretilen cipslerin fizikokimyasal, tekstürel o̊zellikleri ve akrilamid içerikleri}

\author{
Sümeyra Uğur1 (iD), Bedia Şimşek ${ }^{2}$ *(D) \\ 1,2 Süleyman Demirel Üniversitesi, Mühendislik Fakültesi Gıda Mühendisliği Bölümü, 32260 Isparta Türkiye
}

\begin{abstract}
The aim of this study is to evaluate some properties (acrylamide content, textural, and sensory) of cheese chips produced from the teleme of white cheese. Cheese chips were flavored with sucrose and stevia, salt, and evaluated against the control group (without salt, stevia, and sucrose). Cheese dough formulations were thinned to the thickness of chips and turned into round-shaped chips and fried in the oven at the specified temperature and time $\left(180^{\circ} \mathrm{C}, 6 \mathrm{~min}\right.$. $)$. The produced chips were packed and stored at $+4{ }^{\circ} \mathrm{C}$ for 30 days. The difference between chips and storage time of $\mathrm{pH}$, lactic acid (\%), and water activity analysis was found to be statistically significant $(\mathrm{p}<0.05)$. The sucrose (CSU) added chips were determined to be harder but less brittle than the stevia added chips (CST). The acrylamide value was found between $0.218 \mathrm{ppm}$ and $0.573 \mathrm{ppm}$ (with sucrose sample) in cheese chips. The acrylamide content of cheese chips was determined below the legal limit. All chips produced were found to be generally acceptable. Starting from the most liked according to the total sensory score, the ranking is as follows; saline (CSA), control (CNA), stevia (CST), and sucrose (CSU) sample.
\end{abstract}

Keywords: Cheese chips, white cheese, Acrylamide, Stevia

\section{Introduction}

Ready for immediate consumption, long shelf life, easily transportable chips, biscuits, nuts, crackers, etc. products are called snack foods [1]. Most of these foods are of cereal origin, high fat and sucrose content, low nutritious and fried products [2]. Chips are the most important group among snack foods. Potato chips are among the most consumed chips [3]. At the same time, as an alternative to potato chips, chips were produced from different raw materials such as wheat chips [4], tarhana chips [5], corn chips [6], gluten chips [7], and carrot chips [8].

Turkish white cheese is obtained by pasteurizing raw cow's milk, adding calcium chloride and mesophilic starter culture, coagulating with proteolytic enzymes, separating whey from the curd, and shaping of the curd [9]. Different cheeses have been used in snack production by some
Özet

$\mathrm{Bu}$ çalışmanın amacı, beyaz peynirinin telemesinden üretilen peynir cipslerinin bazı özelliklerini (akrilamid içeriği, tekstür ve duyusal) değerlendirmektir. Peynir cipsleri şeker, stevia, tuz ile tatlandırılarak, kontrol grubuna (tuz, stevia ve şeker ilavesiz) karşı değerlendirilmiştir. Peynirin hamur formülasyonları cips kalınlığına kadar inceltilerek yuvarlak hale getirilerek, belirtilen sicaklık ve sürede $\left(180{ }^{\circ} \mathrm{C}, 6\right.$ dakika) firında kızartılmıștır. Üretilen cipsler ambalajlanarak, + $4^{\circ} \mathrm{C}^{\prime} \mathrm{de} 30$ gün süreyle depolanmıştır. Cipslerin $\mathrm{pH}$, laktik asit (\%) ve su aktivite analizinin depolama süresi arasındaki fark istatistiksel olarak anlamlı bulunmuștur $(p<0.05)$. Şeker $(C S U)$ eklenen cipslerin, stevia eklenen cipslerden (CST) daha sert ancak daha az kırılgan olduğu belirlenmiştir. Akrilamid değeri peynir cipslerinde 0.218 ppm ile 0.573 ppm (şekerli numune) arasında bulunmuştur. Peynir cipslerinin akrilamid içeriği yasal sınırın altında belirlenmiștir. Üretilen tüm cipslerin genel olarak kabul edilebilir olduğu görülmüştür. Toplam duyusal puana göre en çok beğenilenlerden başlayarak sıralama şu şekildedir; tuzlu (CSA), kontrol (CNA), stevia (CST) ve şekerli (CSU) numune.

Anahtar kelimeler: Peynir cipsi, Beyaz peynir, Akrilamid, Stevia

researchers. Rakcejeva et al. [10] produced a snack from Cheddar cheese using a vacuum microwave dryer. In other research, puffed snacks were obtained from slicing ripened Harzer cheese. They were produced by hot air application (at $44 \pm 5{ }^{\circ} \mathrm{C}$ until $72 \pm 5 \%$ dry matter) in vacuum microwave dryer [11]. Liu et al. [12] were studied on textural and microstructural properties of microwave-puffed cheese chips.

Acrylamide is a molecule formed by processing carbohydrate-rich foods at high temperatures $\left(100-120^{\circ} \mathrm{C}\right.$ and higher). Acrylamide, a potential carcinogenic substance, is formed during processes such as frying, baking, and roasting in foods, resulting in high temperature and low humidity conditions. The highest amount of acrylamide found in foods containing high amounts of carbohydrates $(100-4000 \mu \mathrm{g} / \mathrm{kg})$. Researchers have reported that foods with high protein content $(<100 \mu \mathrm{g} / \mathrm{kg})$ have low

\footnotetext{
* Sorumlu yazar / Corresponding author, bediasimsek@sdu.edu.tr, Phone:+902462111541

Geliș / Recieved: 04.05.2021 Kabul / Accepted: 05.07.2021 Yayımlanma / Published: 27.07.2021

doi: 10.28948 /ngmuh.932609
} 
acrylamide levels [13, 14]. The highest amount of acrylamide was found in potato chips (117-2762 ppb), while the lowest amount of acrylamide was determined in milk and dairy products $(<10-43 \mathrm{ppb})$. It has been reported that acrylamide could not be detected in foods such as milk, butter, cheese, etc. [15]. This is due to the fact that potatoes contain high levels of asparagine amino acids and after this amino acid reacts with reducing sugars at high temperatures, thereby accelerates the formation of acrylamide [16].

Snack products such as chips are consumed by different consumers (age, gender, etc.). Therefore, snacks can be produced in different varieties such as bitter, sweet, salty, and spicy. The emergence of health-related disorders such as weight gain, metabolic syndrome and diabetes has led to increased interest in foods with reduced fat and sugar [17]. Stevia is a natural substance with properties such as 250 300 times sweeter than sucrose, stable up to $200^{\circ} \mathrm{C}$, high $\mathrm{pH}$ stability, etc. [18].

There is no study on the production of chips produced from teleme of Turkish white cheese, containing only sucrose, stevia, and salt without any additives. In this study, it was aimed to determine whether the teleme of Turkish white cheese can be used as an alternative raw material for chips. In addition, another aim of the study is to examine the effects of sucrose, salt and stevia added to the teleme of Turkish white cheese chips on acrylamide content of the chips. Then, chemical, physical, microbiological, and sensory properties of chips were determined.

\section{Materials and methods}

\subsection{Cheese production}

In this study, the teleme of Turkish white cheeses was produced by the plant of Isparta Unsut (Isparta, Turkey). Pasteurized cow milk was used in the production of the teleme of Turkish white cheese. The method recommended by Hayaloglu et al. [9] was used in the production of teleme of Turkish white cheese. Salting was not applied to the cheeses to be used in the production of chips. Cheeses were freshly used after whey was removed.

\subsection{Chips production}

Stevia, (Takita, Stevia Sweetener, İzmir, Turkey), sucrose (Local market-Isparta Turkey), and salt (Local market- Isparta Turkey) were used in the production of cheese chips. No other additives were added to the cheese chips formulation. The teleme of Turkish white cheese was first cut into small pieces. Then, these pieces were kneaded by hand until they formed a smooth dough for about 10 minutes. The teleme of Turkish white cheese dough (3000 g) was divided into four equal pieces. Sucrose (20\% - CSU), stevia (2\% - CST), salt (4\% - CSA) was added to each piece. The last piece without any addition was separated as the control group (CNA). Then, the chips dough formulations were given in round shape. Pre-drying, baking and final drying processes were applied to the chips in the drying oven (Wiseven, WOF-155, Korea) respectively as follows; 90 minutes at $55^{\circ} \mathrm{C}, 6$ minutes at $180{ }^{\circ} \mathrm{C}$ and 15 minutes at $55^{\circ} \mathrm{C}$. The chips produced are shown in Fig. 1. Cheese chips were packaged using polyethylene (PE) packaging material, which was closed with non-vacuum only hot press application (4 pieces in each package). The chips produced are shown in Fig. 2. Cheese chips were stored at $4{ }^{\circ} \mathrm{C}$ for 30 days. Chemical, physical, microbiological, and sensorial properties of cheese chips were analyzed on the first day and 30th day of storage. This study was carried out three times.

White cheese teleme (Unsalted)

$\downarrow$

Crushing of Teleme Cheese and Converting into Dough $\downarrow$

Dividing of the dough into 4 equal parts

Sweetener Addition

CSU (20\% Sugar) / CST (2\% Stevia) / CSA (4\% Salt) / CNA (Control)

$\downarrow$

Preparation of Dough Formulations $\downarrow$ Pre-Dry $\left(55^{\circ} \mathrm{C} / 90 \mathrm{~min}.\right)$

$\downarrow$

Drying $\left(180^{\circ} \mathrm{C} / 6 \mathrm{~min}\right.$.)

$\downarrow$

Final Drying $\left(55^{\circ} \mathrm{C} / 15 \mathrm{~min}\right.$.)

$\downarrow$

Storage $\left(+4{ }^{\circ} \mathrm{C} / 30\right.$ days $)$

Figure 1. Flow chart of Turkish white cheese chips production

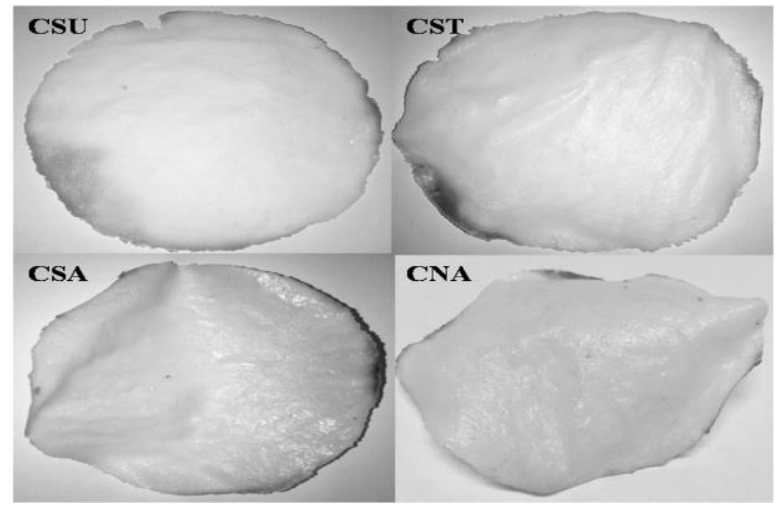

Figure 2. Turkish white cheese chips samples (CSU: sugared, CST: stevial, CSA: salted, CNA: control)

\subsection{Physical and chemical analysis}

Thickness and diameter of cheese chips were measured using digital calipers (0.001 mm, Mitutoyo, Tokyo, Japan) [19]. The values of dry matter, $\mathrm{pH}$ (Weilheim, Germany), titration acidity (LA\%) and fat\% were determined in the teleme of Turkish white cheese [20]. In cheese chips, dry matter [20], water activity (aw) (Novasina, Lab Touch-aw, Lachen, Switzerland), pH (Weilheim, Germany), titration acidity (LA\%); fat [20] analyzes were performed. Total protein contents of cheese chips were determined by Dumathermnitrogen-determination system run under the 
combustion method (Gerhardt Analytical Systems, Dumatherm, Germany) [21].

\subsection{Acrylamide analysis}

Sample preparation: Acrylamide analysis was performed on the 1st and 30th storage days in cheese chips. For this analysis, homogenized $1 \mathrm{~g}$ cheese chips sample was centrifuged at $0{ }^{\circ} \mathrm{C}$ for 20 minutes with $10 \mathrm{ml}$ of $0.1 \mathrm{~N}$ formic acid solution. After removing the upper layer of oil, $2 \mathrm{ml}$ of the aqueous extract separated from the solid precipitate was taken and filtrated through a $0.45 \mu \mathrm{m}$ filter, and then filtrated through a pre-conditioned $(2 \mathrm{ml}$ acetone and $2 \mathrm{ml}$ $0.1 \mathrm{~N}$ formic acid) CarboPrep TM $200 \mathrm{SPE}$ tube. The solid phase extraction (SPE) tube was washed with $1 \mathrm{ml}$ of water and vacuumed for 1 minute to dry the excess water. Two $\mathrm{ml}$ of acetone was filtrated through the vacuumed solid phase extraction (SPE) tube, the filtrate was taken into the vial. Acrylamide analysis was carried out using GC-MS device (Agilent 7890A, GC 5975C MS, 7693B Autosampler) and DB-Wax (30 m x $0.25 \mathrm{~mm}$; film thickness $0.2 \mu \mathrm{m}$ ) column (selected ion monitoring-SIM)) in the selective ion imaging (selected ion monitoring-SIM) mode [22]. The programs used in the analysis are as follows; Computer program MSDCHEM was used in the analysis. In the column temperature program, after waiting 1 minute at $60{ }^{\circ} \mathrm{C}$, it reached $240{ }^{\circ} \mathrm{C}$ with an increase of $20{ }^{\circ} \mathrm{C}$ per minute and kept for 20 minutes at this temperature. Chromatographic conditions: the carrier gas is Helium (He, $1 \mathrm{~mL}$ min-1), injection volume is $1 \mu \mathrm{L}$, detector and injection temperature is $240{ }^{\circ} \mathrm{C}$ and $250{ }^{\circ} \mathrm{C}$. The standard chromatogram and calibration graph are presented in Fig. 3.

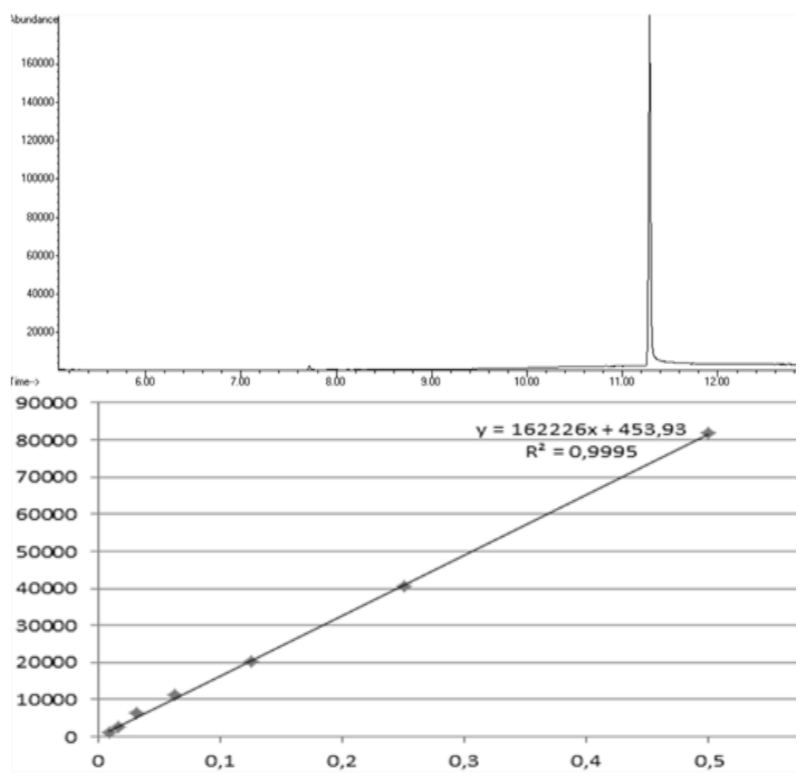

Figure 3. The calibration curve for the determination of acrylamide. Linearity of the method in standard (calibrating) solutions, (y) concentration acrylamide $(\mathrm{mg} / \mathrm{mL}),(\mathrm{x})$ peak area (arbitrary units).

\subsection{Color analysis}

The color analysis of the chips samples was determined using a portable CR-400 tristimulus colorimeter (Minolta
Chroma Meter CR 400 model Osaka, Japan) and Spectra Match software, set to $\mathrm{L}^{*}, \mathrm{a}^{*}, \mathrm{~b}^{*}$ mode. The methods given by Hua et al. [23] were applied in the use of the colorimeter.

Color changes were documented over the duration of the experiment. $\mathrm{L}^{*}$ values indicate lightness (black $\left[\mathrm{L}^{*}=0\right]$ and white $\left[\mathrm{L}^{*}=100\right]$ ), $\mathrm{a}^{*}$ values indicate redness-greenness (red $\left[\mathrm{a}^{*}=100\right]$ and green $\left.\left[\mathrm{a}^{*}=-100\right]\right), \mathrm{b}^{*}$ values indicate yellowness-blueness (yellow $\left[b^{*}=100\right]$ and blue $\left[b^{*}=\right.$ $100])$. The $L^{*}, a^{*}$, and $b^{*}$ values obtained from each cheese chips at the time of sampling represent average $\mathrm{L}^{*}, \mathrm{a}^{*}$, and $b^{*}$ values calculated from three separate light pulses from the colorimeter. A white plate was used for calibration ( $Y=92.7, x=0.3160, y=0.3321)$. Each chips sample was placed on a white table, and $\mathrm{L}^{*} \mathrm{a} \mathrm{b}^{*}$ color measurements were taken in triplicate.

\subsection{Texture analysis}

Texture analysis of chips samples were carried out using texture analysis device (Texture Stable Micro Systems, TAXT Plus, UK). Six chips samples were used for each experiment using probe speed $1 \mathrm{~mm} / \mathrm{s}$ and $7 \mathrm{~mm}$ distance (probe-chip surface distance) values. Three Point Bend Rig probe was used to predict the crispness of cheese chips. Hardness $(\mathrm{N})$ and brittleness $(\mathrm{mm})$ values of chips samples were determined. The maximum force applied to the samples was associated with the hardness of the chip, and the deformation value to which the maximum force was applied was associated with the brittleness of the chips [24].

\subsection{Sensorial analysis}

Sensorial evaluation was carried out by a panelist group experienced in sensorial evaluation at Süleyman Demirel University, Faculty of Engineering, Department of Food Engineering. The panelist group (10 people) consisted of 5 men and 5 women between the ages of 25-35. Samples were encoded with 3-digit randomly selected numbers. In sensorial evaluation, four types of cheese chips were served to the panelists with a glass of water. Chips samples were evaluated using descriptive words expressing color and appearance, structure and crispness, smell, taste, and general acceptability. It was applied according to the methods suggested by Lawless and Heymann [25]. Color and appearance, texture and crispness, taste and odor parameters are in the range of $1-5$ points; the general acceptability parameter is scored between 1-9 points.

\subsection{Statistical analysis}

SPSS 22.0 statistics program was used in the statistical evaluation of this study. Tukey test $(\mathrm{P}<0.05)$ was used to determine the difference between the groups [26]. As Multiple Variable Analysis, Principal Component (PCA) Analysis was applied to the samples, and Xlstat Trial version (2020) package program was used for the statistical evaluation of the data.

\section{Results and discussions}

\subsection{Some chemical properties of Turkish white cheese and chips}

Chemical analysis results of Turkish white cheese used in chips production; dry matter was $36.73 \pm 1.11 \%$, fat 
$14.33 \pm 0.58 \%, \mathrm{pH} \quad 5.28 \pm 0.17$, titration acidity (LA\%) $1.02 \pm 0.27$. The results of chemical analysis of Turkish white cheese are similar to the findings of Pappa et al. [27].

Chemical and physical analysis results of cheese chips are given in Table 1. However, the dough thickness of cheese chips was the same in all samples, they were determined in the value of $0.03-0.06 \mathrm{~mm}$ after baking in the oven and their diameters in the value of 2.95-3.34 mm. When diameter values of the chips were analyzed statistically, the difference between the samples was not found significant $(\mathrm{P}>0.05)$. It is reported in the literature that the thickness of potato chips should be 1-2 mm in order to have good texture properties [28]. The thickness of all cheese chips is similar to the conventional thickness of the potato chips.

Dry matter content in chips samples was determined between 94.91 and 96.02. The dry matter value of gluten chips enriched with food industry by-products was determined in the range of $92.73-95.44 \%$ [7]. The dry matter values of Turkish white cheese chips are similar to the study on gluten chips.

When the fat contents of chips samples were analyzed statistically, the difference between the samples was found significant $(\mathrm{P}<0.05)$. The highest fat rate was determined in the control (CNA) sample $(36.50 \%)$. The lowest fat rate was detected in chips produced with the addition of sucrose $(21.00 \%)$. It is thought that the addition of sucrose reduces the fat percentage. The low-fat content of the chips makes it well flavored and crispy [29]. In a study on tortilla chips, it was stated that the fat rate varies between $21-34 \%$ depending on the raw material used in production and production conditions [30].

The difference between the samples for protein results in Turkish white cheese chips was statistically significant $(\mathrm{P}<0.05)$. Since sucrose in the samples taken for protein determination are part of the dry matter, the protein content of the samples containing sucrose was found to be low. Protein values of cheese chips (26.74-47.94\%) were higher than the average protein values of dried Cheddar cheese $(31.16 \%)$, and chips tarhana $(15.29 \%)[10,5]$.

The color accepted by consumers in chips is the yellow color defined as golden yellow formed because of maillard reaction [31]. Color values of chips samples are given in Table 1. The statistical difference between the color values $(\mathrm{L} *$ and $\mathrm{a} *$ ) was found significant in the cheese chips ( $\mathrm{P}$ $<0.05)$. The highest $L^{*}$ value was found as 73.77 in sucroseadded chips sample (CSU). While the lowest $\mathrm{a}^{*}$ value is seen in salt-added chips (CSA) sample (-2.85), the highest $a^{*}$ value was observed in sucrose-added chips (CSU) (1.89). The $b^{*}$ value of the samples was determined between 3.16 and 4.10. $\mathrm{L}^{*}$ and $\mathrm{a}^{*}$ values of the chips with stevia were similar to the control group. However, these values were found to be higher in samples with sucrose and salt. It is known that sucrose and salt are two effective substances on refraction of light. It is thought that the addition of these two substances may have caused the change in color values.

The difference between cheese chips and time for $\mathrm{pH}$ value was found statistically significant in stevia-added $(\mathrm{CST})$ and control $(\mathrm{CNA})$ samples $(\mathrm{P}<0.05)$. The $\mathrm{pH}$ value of sucrose-added (CSU) and salt-added (CSA) samples was similar during storage. The $\mathrm{pH}$ value of the chips was found to be lower than the potato chips [32].

The titration acidity (LA\%) value of the chips samples during storage was lowest in the sucrose added (CSU) sample on the first storage day $(1.13 \%)$ and highest in the control (CNA) sample $(1.83 \%)$ on the $30^{\text {th }}$ storage day (Table 2). Titration acidity value of the potato chips samples was determined to be $0.1-0.2 \mathrm{mg} / 100 \mathrm{~g}$ [32]. Cheese, the raw material of cheese chips, is a product produced by the addition of lactic acid bacteria. Hence, the $\mathrm{pH}$ and titration acidity of chips were higher than potato chips. Sugar covers a significant part of the dried matter in the chips sample. It is thought that this may have caused the titration acidity to below.

The highest water activity value on the first day of storage was found in stevia-added (CST) sample (0.53), while the lowest water activity value was detected in the sucrose-added (CSU) sample (0.35). The difference between the samples and time in the water activity (aw) results of Turkish white cheese chips was statistically significant $(\mathrm{P}<0.05)$. It was seen that the water activity values of the Turkish white cheese chips increased at the end of the storage. It is understood that suitable conditions occur at the end of storage in cheese chips samples for the growth of yeast and mold. In addition, the relationship between water activity and lipid oxidation has been known for many years [33]. Since cheese chips samples are a food containing saturated and unsaturated fats, the increase in water activity can also be associated with rancidity and oxidative deterioration in the samples.

\subsection{Acrylamide analysis}

It has been reported by researchers that health hazardous compounds such as acrylamide can be formed when chips products are subjected to high temperature baking and frying processes. Acrylamide is reported to cause carcinogenic and neurotoxic effects above these values [34]. In countries such as the Netherlands and the United States the short-term daily intake of acrylamide with food is 0.3-2 $\mu \mathrm{g} / \mathrm{kg} / \mathrm{day}$, long-term intake varies according to biological effects such as age, race, or food consumption habits in the population [35].

Acrylamide contents of Turkish white cheese chips are given in Table 2. The difference between samples and storage times is statistically significant on the acrylamide values of chips $(\mathrm{P}<0.05)$. Acrylamide results of cheese chips increased during storage; the highest acrylamide value was observed in the sucrose-added (CSU) sample. It is believed that this is due to the maillard reaction between reducing sucrose and amino groups known as the mechanism by which acrylamide formation occurs under the influence of sugar.

It is known that increase in temperature and time increases the formation of acrylamide [13]. The study with biscuits carried out by Summa et al. [36] showed an inverse relationship between moisture content and the amount of acrylamide formation. 
Table 1. Physico-chemical analysis results in white cheese cheese chips $(n=3)$

\begin{tabular}{ccccc}
\hline \multirow{2}{*}{ Chemical and Physical Analysis } & \multicolumn{4}{c}{ Chips Samples $\dagger$} \\
\cline { 2 - 5 } & CSU $^{*}$ & CST $^{*}$ & CSA $^{*}$ & CNA $^{*}$ \\
\hline Dry Matter (\%) & $96.02 \pm 0.60^{\mathrm{a}}$ & $94.91 \pm 0.34^{\mathrm{ab}}$ & $95.51 \pm 0.05^{\mathrm{a}}$ & $95.10 \pm 0.72^{\mathrm{ab}}$ \\
Fat (\%) & $23.50 \pm 0.50^{\mathrm{d}}$ & $31.50 \pm 1.50^{\mathrm{c}}$ & $33.50 \pm 0.50^{\mathrm{abc}}$ & $36.50 \pm 0.50^{\mathrm{a}}$ \\
Protein (\%) & $26.74 \pm 0.64^{\mathrm{b}}$ & $45.81 \pm 0.02^{\mathrm{a}}$ & $45.48 \pm 0.40^{\mathrm{a}}$ & $46.83 \pm 0.41^{\mathrm{a}}$ \\
Diameter (mm) & $3.21 \pm 0.01^{\mathrm{a}}$ & $3.22 \pm 0.02^{\mathrm{a}}$ & $3.23 \pm 0.02^{\mathrm{a}}$ & $3.22 \pm 0.02^{\mathrm{a}}$ \\
$L^{*}$ & $73.77 \pm 2.31^{\mathrm{a}}$ & $64.12 \pm 0.02^{\text {cde }}$ & $71.55 \pm 1.11^{\mathrm{ab}}$ & $64.55 \pm 0.27^{\mathrm{be}}$ \\
$a^{*}$ & $-1.89 \pm 0.07^{\mathrm{c}}$ & $-2.69 \pm 0.04^{\mathrm{ab}}$ & $-2.85 \pm 0.01^{\mathrm{a}}$ & $-2.56 \pm 0.16^{\mathrm{ab}}$ \\
$b^{*}$ & $3.20 \pm 0.47^{\mathrm{a}}$ & $3.16 \pm 0.56^{\mathrm{a}}$ & $4.10 \pm 0.42^{\mathrm{a}}$ & $3.28 \pm 0.04^{\mathrm{a}}$ \\
\hline
\end{tabular}

*The different letters show that the difference between the samples is statistically important $(\mathrm{P}<0.05)$.

$\dagger$ CSU: sucrose, CST: stevia, CSA: salt, CNA: plain, L*: lightness, a*: redness, $\mathrm{b}^{*}$ : yellowness

Table 2. The chemical and textural analysis results in white cheese chips $(n=3)$

\begin{tabular}{|c|c|c|c|}
\hline \multirow{2}{*}{ Chemical Analysis } & \multirow{2}{*}{$\begin{array}{l}\text { Chips } \\
\text { Samples } \dagger\end{array}$} & \multicolumn{2}{|c|}{ Storage Period (day)* } \\
\hline & & 1 & 30 \\
\hline \multirow{4}{*}{ Water activity (aw) } & $\mathrm{CSU}$ & $0.35 \pm 0.03^{\mathrm{f}}$ & $0.64 \pm 0.03^{\mathrm{a}}$ \\
\hline & CST & $0.53 \pm 0.01^{\text {b-e }}$ & $0.64 \pm 0.02^{\mathrm{a}}$ \\
\hline & CSA & $0.47 \pm 0.02^{\text {def }}$ & $0.61 \pm 0.00^{\mathrm{a}-\mathrm{d}}$ \\
\hline & $\mathrm{CNA}$ & $0.38 \pm 0.05^{\mathrm{ef}}$ & $0.62 \pm 0.03^{\mathrm{abc}}$ \\
\hline \multirow{4}{*}{$\mathrm{pH}$} & $\mathrm{CSU}$ & $5.38 \pm 0.12^{\mathrm{ab}}$ & $5.40 \pm 0.10^{\mathrm{ab}}$ \\
\hline & CST & $5.22 \pm 0.05^{\mathrm{b}}$ & $5.42 \pm 0.04^{\mathrm{ab}}$ \\
\hline & CSA & $5.39 \pm 0.28^{\mathrm{ab}}$ & $5.57 \pm 0.21^{\mathrm{ab}}$ \\
\hline & CNA & $5.21 \pm 0.18^{\mathrm{b}}$ & $5.72 \pm 0.00^{\mathrm{a}}$ \\
\hline \multirow{4}{*}{ LA $(\%)$} & CSU & $1.13 \pm 0.27^{\mathrm{b}}$ & $1.37 \pm 0.14^{\mathrm{ab}}$ \\
\hline & CST & $1.57 \pm 0.16^{\mathrm{ab}}$ & $1.70 \pm 0.35^{\mathrm{ab}}$ \\
\hline & CSA & $1.51 \pm 0.22^{\mathrm{ab}}$ & $1.75 \pm 0.41^{\mathrm{ab}}$ \\
\hline & CNA & $1.40 \pm 0.13^{\mathrm{ab}}$ & $1.83 \pm 0.10^{\mathrm{a}}$ \\
\hline \multirow{4}{*}{ Acrylamide (ppm) } & CSU & $0.543 \pm 0.133^{\mathrm{a}}$ & $0.573 \pm 0.071^{\mathrm{a}}$ \\
\hline & CST & $0.226 \pm 0.010^{\mathrm{cd}}$ & $0.293 \pm 0.008^{\mathrm{a}-\mathrm{d}}$ \\
\hline & CSA & $0.360 \pm 0.062^{\mathrm{abc}}$ & $0.497 \pm 0.202^{\mathrm{ab}}$ \\
\hline & CNA & $0.218 \pm 0.065^{\mathrm{cd}}$ & $0.261 \pm 0.017^{\mathrm{bcd}}$ \\
\hline \multirow{5}{*}{ Hardness (N) } & CSU & $0.68 \pm 0.33$ & $0.68 \pm 0.44$ \\
\hline & CST & $0.74 \pm 0.33$ & $1.03 \pm 0.46$ \\
\hline & CSA & $0.46 \pm 0.01$ & $0.59 \pm 0.27$ \\
\hline & $\mathrm{CNA}$ & $0.73 \pm 0.24$ & $1.08 \pm 0.39$ \\
\hline & $\mathrm{CSU}$ & $27.80 \pm 0.50^{\mathrm{c}}$ & $26.07 \pm 0.46^{\mathrm{d}}$ \\
\hline \multirow{4}{*}{ Brittleness (mm) } & CST & $28.35 \pm 0.46^{\mathrm{c}}$ & $29.44 \pm 0.50^{\mathrm{b}}$ \\
\hline & CSA & $29.56 \pm 0.48^{\mathrm{b}}$ & $31.88 \pm 0.50^{\mathrm{a}}$ \\
\hline & $\mathrm{CNA}$ & $31.93 \pm 0.45^{\mathrm{a}}$ & $31.36 \pm 0.50^{\mathrm{a}}$ \\
\hline & $\mathrm{CSU}$ & $27.80 \pm 0.50^{\mathrm{c}}$ & $26.07 \pm 0.46^{\mathrm{d}}$ \\
\hline
\end{tabular}

Accordingly, the amount of acrylamide increases exponentially as the amount of moisture decreases. In another study, the amount of acrylamide was determined at a high rate in foods with high carbohydrate in heat treatments above $100-120^{\circ} \mathrm{C}$, while it was found in lower amounts $(100<\mu \mathrm{g} / \mathrm{kg})$ in foods with high protein [37]. In a study, very high amounts of acrylamide (1.1ppm) were found in potato chips. It is reported that approximately $10 \mathrm{~g}$ of potato chips contain $20 \mathrm{ng}$ of acrylamide [38]. In sucroseadded cheese chips $(0.543-0573 \mathrm{ppm})$, which have the highest acrylamide content during storage, this rate is about half the rate in cheese chips. The upper limits of acrylamide intake allowed in the European Union are stated as 0.5-0.8 $\mu \mathrm{g} / \mathrm{kg} / \mathrm{day}$ in foods and $0.1 \mu \mathrm{g} / \mathrm{l}$ in water [39]. The acrylamide content of Turkish white cheese chips was determined below the legal limit.

\subsection{Texture values}

Hardness $(\mathrm{N})$ and brittleness $(\mathrm{mm})$ values of teleme cheese chips are given in Table 2. When the hardness results of the chips were analyzed statistically, there was no difference between the samples $(\mathrm{P}>0.05)$. In our study, the change in textural hardness of the samples related to storage is similar to the studies in the literature. In the study conducted by Kayacier and Singh [40] it was stated that the hardness value of tortilla chips stored for 4 weeks remained unchanged at the end of storage. In another study on carrot chips, it was observed that there was no change in the hardness value of the samples during storage periods up to 
5 months [8]. Also in the study carried out by Chudy et al. [11] hardness value of puff snacks produced after the application of hot air drying $\left(44 \pm 5^{\circ} \mathrm{C}\right.$, until production of $72 \pm 5 \%$ dry matter) and vacuum microwave drying processes on sliced plain Harzer cheese (acid-set ripened) was found in the range of 2.84-6.82 N, in the 0-120 minutes, and the hardness value of Turkish white cheese chips (0.45$1.08 \mathrm{~N}$ ) was found to be lower than the puff snacks. When the brittleness values of Turkish white cheese chips are examined, the highest brittleness value was determined on the $1^{\text {st }}$ day plain (CNA) sample $(31.93 \mathrm{~mm})$ and the lowest brittleness value was determined onthe $30^{\text {th }}$ day sucrose added (CSU) sample $(26.07 \mathrm{~mm})$. CSU is supported by sensorial analysis results that the sample is softer and more elastic than other samples. In addition, salt is thought to be effective on brittleness. It was observed that the difference between the samples was significant in the brittleness results $(\mathrm{P}<0.05)$. In the study conducted by Ulusoy [41] it was stated that brittleness (deformation) value of biscuit produced because of decrease in sugar ratio and increase in stevia increased and the hardness value decreased. Stevia was found to be effective in brittleness of biscuits compared to sugar. Turkish white cheese chips samples also showed that CSU sample was harder but less brittle than the stevia added (CST) sample. In the study carried out by Chudy et al. [11] brittleness value of puff snacks produced after the application of hot air drying (at $44 \pm 5{ }^{\circ} \mathrm{C}$, until production of $72 \pm 5 \%$ dry matter) and vacuum microwave drying processes on sliced plain Harzer cheese (acid-set ripened) was found in the range of $3.20-10 \mathrm{~mm}$, in the $0-120$ minutes. Brittleness results of Turkish white cheese chips were found over the findings of Chudy et al. [11].

\subsection{Sensorial analysis}

Sensory analysis results and statistical evaluations of Turkish white cheese chips are given in Table 3 . When the sensorial analysis results of the Turkish white cheese chips during the storage were analyzed statistically, the difference between the color and appearance parameter was found insignificant $(\mathrm{P}>0.05)$; the statistical difference between the samples in texture and crispness, taste and smell, general acceptability parameters were found significant $(\mathrm{P}<0.05)$.

It is supported by sensorial analysis results that the CSU chip is softer and more elastic than other samples. For this reason, the cheese chips with sucrose added had low scores in terms of their sensorial properties. However, taste and smell parameters were evaluated better in these chips. In stevia (CST) chips, although the color and appearance, texture and crispness, general acceptability parameters are interpreted positively, the taste and smell parameter caused these chips to be scored low due to the taste effect in the mouth by the stevia. Salted (CSA) chips received the most appreciation in terms of taste and smell properties. It was determined that the general acceptability of salted (CSA) and plain (CNA) chips is higher than other samples.

\subsection{Principal component analysis}

The sensorial (color and appearance, texture and crispness, taste and smell, general acceptability), texture (hardness, texture-brittleness) and some chemical properties (acrylamide) of cheese chips were analyzed using the principal component analysis (PCA). The principal component analysis model was developed with 8 components. These components explain $58.90 \%$ of the total variance. The first principal component explains $23.87 \%$ of the total variance and the second principal component explains $35.03 \%$. The eigenvalue value of the first principal component was found as 9.45 and that of the second principal component was 6.44 .

The order of the first principal component according to their distance from zero and having the same sign is as follows: Color and appearance 0.22 , texture and crispiness 0.27 , taste and appearance 0.26 , hardness 0.18 , roughness 0.20 , sound 0.26 , elastic-brittleness 0.28 , thickness-fineness -0.22 , sugar taste -0.13 . The order of the second principal component is sienna-yellowy 0.74 , matt-yellowish 0.19 , fatty appearance 0.82 , chewiness -0.66 . As can be seen in Figure 4, the first principal component of sample CSA30 (4.79) and CNA30 (2.55) is positively high. The first principal component of CNA (1.89) took this value positively and in the second principal component, CSA has high values 1.16, and CNA with value 2.56. CSU received a negative value in the first principal component such as 5.13, CST -1.64, CSU30 -3.40. CST30 (-1.35) and CSU30 $(-4.24)$ received higher values in the second principal component.

According to these data, it is seen in Fig. 4 that CST and CSU are in melted appearance, burnt smell and taste, high foreign smell rate and sugar taste. It was found that CNA and CSA are products with fatty appearance, yellowish, brighter, high textural brittleness, and crispiness, hard, salted, and with non-elastic properties and high acceptability, and CSU30 and CST30 have the rancid taste and higher acrylamide content than other samples. On the other hand, CNA30 and CSA30 have harder texture, thinner appearance, better chewability and more popular than others.

\section{Conclusions}

In the study, sweet (sucrose and stevia), salted and plain chips were produced from Turkish white cheese. Turkish white cheese chips were produced without adding any fat in the oven and without adding any additives. The cheese chips were determined to have a high protein (26.74\%) and a low acrylamide content (below legal limits). The brittleness value of Turkish white cheese chips was determined the highest in control (CNA) sample and the lowest in CSU sample. Salted (CSA) sample received the most appreciation in terms of total sensorial properties and general acceptability. Others follow it as follows; plain (CNA), stevia (CST), sucrose (CSU). In this study, it has been revealed that sweet and salted cheese chips can offer alternatives to today's consumers in terms of natural and healthy nutrition. It is thought that cheese chips produced with the addition of stevia and sugar may be produced industrially after some other properties are examined. 
Table 3. Sensorial analysis results of cheese chips produced from white cheese $(n=3)$

\begin{tabular}{|c|c|c|c|}
\hline \multirow{2}{*}{$\begin{array}{l}\text { Sensorial } \\
\text { Parameters }\end{array}$} & \multirow{2}{*}{$\begin{array}{l}\text { Chips } \\
\text { Samples } \dagger\end{array}$} & \multicolumn{2}{|c|}{ Storage Period (day) } \\
\hline & & 1 & 30 \\
\hline \multirow{4}{*}{$\begin{array}{l}\text { Color and } \\
\text { Appearance }\end{array}$} & $\mathrm{CSU}$ & $3.20 \pm 0.00$ & $3.50 \pm 0.50$ \\
\hline & CST & $3.00 \pm 0.60$ & $4.35 \pm 0.65$ \\
\hline & CSA & $4.20 \pm 0.20$ & $4.10 \pm 0.90$ \\
\hline & CNA & $4.00 \pm 0.20$ & $4.00 \pm 1.00$ \\
\hline \multirow{4}{*}{ Texture and Crispness } & $\mathrm{CSU}$ & $2.70 \pm 0.10^{\text {cd }}$ & $2.50 \pm 0.50^{\mathrm{d}}$ \\
\hline & CST & $3.90 \pm 0.30^{\mathrm{abc}}$ & $3.50 \pm 0.50^{\mathrm{a}-\mathrm{d}}$ \\
\hline & CSA & $4.00 \pm 0.20^{\mathrm{abc}}$ & $4.00 \pm 1.00^{\mathrm{abc}}$ \\
\hline & $\mathrm{CNA}$ & $4.20 \pm 0.20^{\mathrm{ab}}$ & $3.95 \pm 0.75^{\mathrm{a}}$ \\
\hline \multirow{4}{*}{ Taste and Smell } & $\mathrm{CSU}$ & $3.30 \pm 0.30^{\mathrm{c}}$ & $3.50 \pm 0.50^{\mathrm{bc}}$ \\
\hline & CST & $3.50 \pm 0.50^{\mathrm{bc}}$ & $4.30 \pm 0.30^{\mathrm{ab}}$ \\
\hline & CSA & $4.00 \pm 0.20^{\mathrm{abc}}$ & $4.50 \pm 0.50^{\mathrm{a}}$ \\
\hline & $\mathrm{CNA}$ & $4.00 \pm 0.20^{\mathrm{abc}}$ & $3.75 \pm 0.05^{\mathrm{abc}}$ \\
\hline \multirow{4}{*}{ General Acceptability } & $\mathrm{CSU}$ & $5.20 \pm 0.00^{\mathrm{de}}$ & $4.10 \pm 0.40^{\mathrm{e}}$ \\
\hline & CST & $6.20 \pm 0.40^{\mathrm{cd}}$ & $4.60 \pm 0.60^{\mathrm{e}}$ \\
\hline & CSA & $7.60 \pm 0.40^{\mathrm{ab}}$ & $7.50 \pm 0.50^{\mathrm{ab}}$ \\
\hline & $\mathrm{CNA}$ & $7.15 \pm 0.65^{\mathrm{abc}}$ & $6.50 \pm 0.50^{\mathrm{bc}}$ \\
\hline
\end{tabular}

a-e: Shows that the difference between the samples is important $(\mathrm{P}<0.05)$.

†CSU: sucrose, CST: stevia, CSA: salt, CNA: Control.

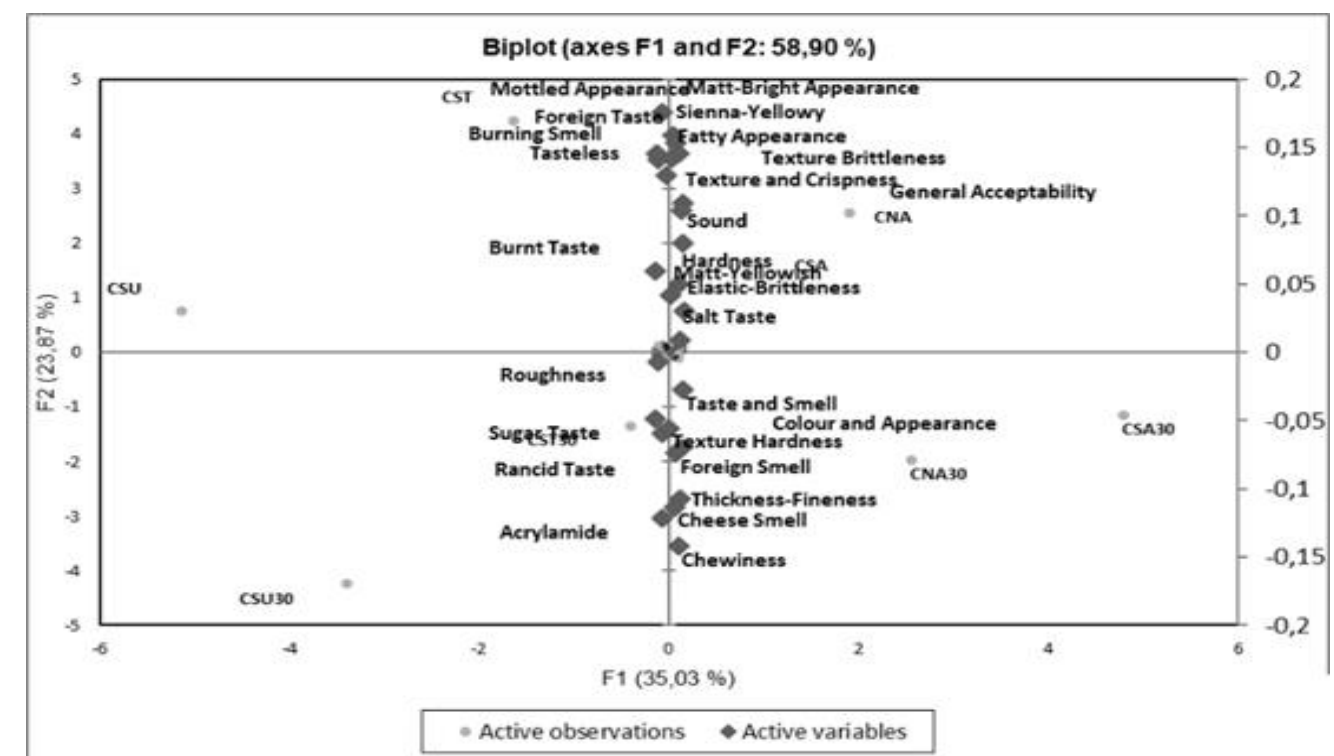

*CSU: sugared, CST: stevia, CSA: salted, CNA: Control (the first day of storage); CSU30, CST30, CSA30 and CNA30 (the $30^{\text {th }}$ day of storage)

Figure 4. Principal component analysis in Turkish white cheese chips samples

\section{Funding}

This research was performed with the financial support of Suleyman Demirel University Scientific Research Projects Coordination Unit-Isparta Turkey, Grant/Award Number: 4860-YL1-17.

Conflict of Interest: The authors declare that they do not have any conflict of interest.

\section{Similarity rate (iThenticate): $6 \%$}

\section{References}

[1] P. Fellows, A. Hampton. Small-scale food processing: a guide to appropriate equipment. Intermediate
Technology Publications 7, 155-156, 1992. https://doi.org/10.1002/pts.2770070306

[2] N. M. Nor, A. Carr, A. Hardacre, C. S. Brennan. The development of expanded snack product made from pumpkin flour-corn grits:effect of extrusion conditions and formulations on physical characteristics and microstructure. Foods 2(2) 160-169, 2013. https://doi.org/10.3390/foods2020160

[3] A. J. McCarthy. The snack industry: history, domestic and global status. Snack Foods Processing, CRC Press, 29-35, 2001.

[4] M. Cankurtaran. Production of fried wheat chips and determination of quality characteristics of the wheat 
chips. Master's Thesis, Erciyes University, Kayseri, 2008.

[5] M. Ozçam. Determination of textural and microbiological properties of tarhana chips. Master's Thesis, Celal Bayar University, Manisa, 2012.

[6] F. Yuksel. Utulization of stale bread in fried wheat and corn chips. PhD Thesis, Erciyes University, Kayseri, 2014

[7] M. Hendek-Ertop, K. Kutluk, K. Coşkun, S. Canl1. A new approach for production of chips with food 1ndustry byproducts: gluten enriched chips. Academic Food Journal 14 (4), 398-406, 2016.

[8] A. Sulaeman, L., Keler, W. D. Giraud, L. S. Taylor, A. J. Driskell. Changes in carotenoid, physicochemical and sensory values of deep-fried carrot chips during storage. International Journal of Food Science and Technology 38, 603-613, 2003. https://doi.org/ 10.1046/j.1365-2621.2003.00689.x

[9] A.A. Hayaloglu, M. Guven, P. F. Fox. Microbiological, biochemical and technological properties of Turkish white cheese 'Beyaz Peynir' International Dairy Journal 12, 635-648, 2002. https://doi.org/10.1016/S0958-6946(02)00055-9

[10] T. Rakcejeva, J. Zagorska, L. Dukalska, R. Galoburda, E. Eglitis. Physical-chemical and sensory characteristics of cheddar cheese snack produced in vacuum microwave dryer. Chemine Technology 3 (52), 16-20, 2009.

[11] S. Chudy, A. Makowska, M. Piatek, M. Krzywdzinska-Bartkowiak. Application of microwave vacuum drying for snack production: characteristics of pure cheese puffs. International Journal of Dairy Technology 72(1) 82-88, 2019. https://doi.org/ $10.1111 / 1471-0307.12562$

[12] L Liu, H. Zhang, X. Li, X. Han, X. Qy, P. Chen, F. Wang, L. Wang. Effect of waxy rice starch on textural and microstructural properties of microwave-puffed cheese chips. International Journal of Dairy Technology 71 (2) 501-511, 2017. https://doi.org/ 10.1111/1471-0307.12437

[13] E. Tareke, P. Rydberg, P. Karlsson, S. Eriksson, M. Toemqvist, Analysis of acrylamide, a carcinogen formed in heated foodstuffs. J. Agric. Food Chem. 50 4998-5006, 2002.

[14] F. Mestagh, B. D. Meulenaer, C. V. Peteghem, Influence of oil degradation on the amounts of acrylamide generated in a model system and in french fries. Food Chemistry 100 1153-1159, 2007.

[15] T. Krishnakumar, R. Visvanathan. Acrylamide in food products: a review. Journal of Food Processing and Technology 5 (7) 344, 2014. https://doi.org/ 10.4172/2157-7110.1000344

[16] C. E. Tamer, B. Karaman. Formation of acyrlamide in foods and it's effects on human health. Jaurnal of Food 31 (4) 195-199, 2006.

[17] R. S. Cadena, H. M. A. Bolini. Time-Intensity Analysis and Acceptance Test for Traditional and Light Vanilla Ice Cream. Food Research International
3 (44) 677-683, 2011. https://doi.org/10.1016/ j.foodres.2010.12.012

[18] M. Soliman. Stevia Plant, Natural Concentrated Sweetenes. Egyptian Society of Sugar Technologists, $28^{\text {th }}$ Annual Conference, December 2-4, 1997

[19] AACC. Approved methods of the AACC the association St. Paul., 2000

[20] TSE. Beyaz Peyniri Standardı TS 591. Türk Standartları Enstitüsü. Necatibey cad. No:112. Bakanlıklar Ankara- Turkiye, 1989.

[21] Anonymous. Handbook of Gerhardt Dumatherm Instruction Manual, C.Gerhardt GmbH \& Co. KG. 2011.

[22] M. Biedermann, S. Biedermann-Brem, A. Noti, K. Grob. Methods for determining the potetional formation and its elemination in raw materials for food preparation, such as potatoes. Mitteilungen aus Lebensmitteluntersuchung und Hygiene 93 653-667, 2002.

[23] X. Hua, K. Wang, R. Yang, J. Kang, H. Yang. Edible coating from sunflower head pectin to reduce lipid uptake in fried potato chips. Food Science and Technology 62 1220-1225, 2015. https://doi.org/ 10.1016/j.lwt.2015.02.010

[24] H. S. Kwak, S. S. Kim, Y. H. Chang, M. Saleh, Y. Lee. Prediction of Sensory Crispness of Potato chips using a reference calibration method. Journal of Food Quality 7 1-6, 2019. https://doi.org/10.1155/2019/ 5462751

[25] H. T. Lawless, H. Heymann. Sensory evaluation of food principles and practices. ( $2^{\text {th }}$ ed.). New York, 2010.

[26] B. J. Winer, D. R. Brown, K. M. Michels. Statistical principles in experimental design. (3th ed.). New York: McGraw-Hill, 1991

[27] E. C., Pappa, I. Kandarakis, E. M.Anifantakis, G. K. Zerfiridis. Influence of types of milk and culture on the manufacturing practices, composition and sensory characteristicsof Teleme cheese during ripening. Food Control 17 570-581, 2006. https://doi.org/10.1016/j.foodcont 2005. 03.004

[28] M. M. A. Basuny, M. M. D. Mostafa, M. A. Shaker. Relationship between chemical composition and sensory evaluation of potato chips made from six potato varieties with emphasis on the quality of fried sunflower oil. World Journal of Dairy \& Food Sciences 4 (2) 193-200, 2009.

[29] W.F. Talburt, O. Smith. Potato processing. (4th ed.). AVI-Van Nostrant Reinhold Company, New York., 1986.

[30] J. K. Lee. The effects of processing conditions and maize varieties on physicochemical characteristics of tortilla chips. PhD Thesis, Texas A \& M University, 1991.

[31] F. Pedreschi, K. Kaack, K. Granby, E. Troncoso. Acrylamide reduction under different pre-treatments 
in french fries. Journal of Food Engineering 79 786793, 2006.

[32] P. K. Caetano, F. A. C. Marino-Nasser, V. Z. Mendonça, K. A. Furlaneto, E. R. Daiuto, R. L. Vieites. Physicochemical and sensory characteristics of sweet potato chips undergoing different cooking methods. Food Science and Technology, Campinas 38 (3) 434-440, 2018.

[33] M. Pala, B. Saygı. Su Aktivitesi ve Gıda işlemedeki önemi. Gıda, 1 33-39, 1983.

[34] R. H. Stadler, I. Blank, N. Varga, F.Robert, P. Hau, A. Guy, M. C. Robert, S. Riediker. Acryla J.mide from maillard reaction products. Nature 419 449-450, 2002.

[35] P. Rydberg, S. Ericson, E. Tareke, P. Karlsson, L. Ehrenberg, M. Tornquvist. Investigations of factors that influence the acrylamide content of heated foodstuffs. Journal of Agriculture and Food Chemistry 51 7012-7018, 2003.

[36] C. Summa, T. Wenzl, M. Brohee, B. De La Calle, E. Anklam. Investigation of the correlation of the acrylamide content and the antioxidant activity of model cookies. Journal of Agricultural and Food Chemistry 54 853-859, 2006.

[37] W. L. Claeys, K. D. Vleeschouwer, M. E.Hendrickx. Quantifying the formation of Carcinogens during food processing acrylamide. Trends in Food Science and Technology 16 181-193. 2005.

[38] E. Dybing, T. Sanner. Risk assessment of acrylamide in food. Toxicol. Science 75 7-15, 2003.

[39] A. Karagoz. Acrylamide and its presence in foods. TAF Preventive Medicine Bulletin 8(2) 187-192, 2009.

[40] A. Kayacier, R. K. Singh. Textural properties of baked tortilla chips. Food Science and Technology 36463 466, 2003.

[41] Ulusoy, S. Determination of the quality features and acrylamide content of biscuits sweetened with stevia. Master's Thesis, Mersin University, Mersin, 2011. 